\title{
The Second High Climb
}

\section{Author(s): George I. Finch}

Source: The Geographical Journal, Vol. 60, No. 6 (Dec., 1922), pp. 413-422

Published by: geographicalj

Stable URL: http://www.jstor.org/stable/1781078

Accessed: 27-06-2016 05:06 UTC

\section{Your use of the JSTOR archive indicates your acceptance of the Terms \& Conditions of Use, available at}

http://about.jstor.org/terms

JSTOR is a not-for-profit service that helps scholars, researchers, and students discover, use, and build upon a wide range of content in a trusted digital archive. We use information technology and tools to increase productivity and facilitate new forms of scholarship. For more information about JSTOR, please contact support@jstor.org.

The Royal Geographical Society (with the Institute of British Geographers), Wiley are collaborating with JSTOR to digitize, preserve and extend access to The Geographical Journal 


\section{THE SECOND HIGH CLIMB}

\section{Captain George I. Finch}

THE climbing of Mount Everest is a tremendous proposition. With a clear realization of this, I joined the expedition, ready to do my share in the conquest of the mountain by every means at our disposal. Optimism may be the attribute of fools; but they say that experience teaches even such, and my experience of Alpine climbing had already taught me that no stiff mountaineering problem can be tackled with much hope of success unless one believes wholeheartedly in the possibility of achievement. I think it was Sir Francis Younghusband who, somewhere or other, referred to the necessity of possessing the faith that removes mountains, and a purpose unhoneycombed with half-heartedness. With such an example in our minds throughout that long and, at times, rather trying journey across Tibet, where it was, perhaps, hard to keep one's optimism always unsullied, it was not impossible for one to cling to the watchword "Everest is climbable, and we shall climb it." Confidence alone were of little avail ; but allied with enthusiasm and respect for the work in hand it engenders that concentration of mind and energy which acts like a searchlight upon the problem, and seeks solutions for the complicated questions of equipment, tactics, and so forth, involved.

A little over a year ago I had considered, somewhat carelessly and superficially I fear, the advantages of using oxygen as an aid to climbing Mount Everest, and had dismissed the idea on the grounds that the weight of any useful supply would be prohibitive. Prof. Dreyer, however, the Professor of Pathology in the University of Oxford, held the strong opinion that Mount Everest would never be climbed without oxygen, and that an ample supply could be provided in a sufficiently portable form to enable the summit to be reached. The question was examined by the Mount Everest Committee with an open mind, with the result that his opinion was endorsed, and it was decided to include oxygen in the equipment of the expedition. The oxygen equipment, consisting of very light steel cylinders for storing the oxygen and an ingenious apparatus for distributing it to the climber, was evolved by Major Stewart and Mr. Eager of the Air Ministry, and Mr. Unna, in close co-operation with Mr. Davis and Mr. Rosling of the firm of Siebe Gorman \& Co. It was somewhat complicated, but frequent oxygen drill parades were taken very seriously by all members of the party.

There are those who do not believe in oxygen. Perhaps it is because simple obvious facts render them uneasy in their unbelief, that they rush into print with a wholesale condemnation on the grounds that its use in high mountaineering is what they rather loosely term "artificial," and therefore unsporting. Now, few of us, I think, who stop to ponder for a brief second, will deny that our very existence in this enlightened 
twentieth century with all its amenities of modern civilization is, in the same slipshod sense of the word, " artificial." Most of us have learnt to respect progress and to appreciate the meaning and advantages of adaptability. For instance, it is a fairly firmly established fact that warmth is necessary to life. The mountaineer, acting on this knowledge, conserves as far as possible his animal heat by wearing specially warm clothing. No one demurs; it is the common-sense thing to do. He pours his hot tea from a thermos bottle-and never blushes! Nonchalantly, without fear of adverse criticism, he doctors up his inside with special heat- and energy-giving foods and stimulants ! From the sun's ultra-violet rays and the wind's bitter cold, he boldly dares to protect his eyes with Crookes' anti-glare glasses ; further, he wears boots that to the average layman look ridiculous! The use of caffeine to supply just a little more buck to an almost worn-out human frame is not cavilled at despite its being a synthetic drug the manufacture of which involves the employment of complicated plant and methods. If science could prepare oxygen in tabloid form or supply it to us in thermos flasks that we might imbibe it like our hot tea, the stigma of " artificiality" would, perhaps, be effectually removed. But when it has to be carried in special containers, its whole essence is held to be altered, and by using it the mountaineer is taking a sneaking, unfair advantage of the mountain! In answer to this grave charge, I would remind the accuser that, by the inhalation of a little life-giving gas, the climber does not smooth away the rough rociks of the mountain or still the storm; nor is he an Aladdin who, by a rub on a magic ring, is wafted by invisible agents to his goal. Oxygen renders available more of his store of energy and so hastens his steps, but it does not, alas! fit the wings of Mercury on his feet. The logic of the antioxygenist is surely faulty.

I have seen the opinion expressed-presumably by way of supporting the idea of attempting to climb Mount Everest inadequately equipped, i.e. without oxygen-that it is just as important to ascertain how far a man can climb without oxygen as to reach the top by what are called "illegitimate" means. It may be important, but it was not the object which the expedition had to attain.

General Bruce had brought us safely, both mentally and physically, through Tibet to the Base Camp. Put baldly thus, it may sound a small accomplishment; actually, the task was one demanding the highest qualities of generalship and powers of organization. When we left him at the Base, his great fund of energy and cheerful good wishes for success continued to encourage us.

On May 20 Geoffrey Bruce and I arrived at Camp III. We were accompanied by Tejbir, one of the four Gurkha non-commissioned officers on the expedition and as fine a type of Gurkha humanity as one could wish to see. The cylinders containing our oxygen were found to be in good condition; but the apparatus-through no fault of the 
makers, who had, indeed, done their work admirably-leaked very badly, and to get them into satisfactory working order, four days of hard toil with soldering iron; hacksaw, pliers, and all the other paraphernalia of a fitter's shop were necessary. Our workshop was in the open. The temperature played up and down round about $0^{\circ} \mathrm{F}$., but inclined more to the negative side of that irrational scale. Even handling bits of metal in the bitter cold, often with bare hands on account of the delicate nature of some of the repairs, did not prevent Geoffrey Bruce from helping me with that energy, great will, and good nature that he showed so abundantly throughout the whole of our climb together. The masks from which the oxygen was to be breathed proved useless, but by tackling the problem with a little thought and much cheerfulness a satisfactory substitute was eventually evolved. Preparatory to embarking on the climb itself, we went for several trial walks-one over to the Rapiu La, a pass 2 r,, 00 feet high, at the foot of the north-east ridge of Everest, from which we hoped to obtain views of the country to the south. But only part of the north-east ridge showed hazily through drifting mists. Towards the north and looking down the East Rongbuk glacier, views were clearer, though partially obscured by rolling banks of cloud. Colonel Strutt and Dr. Wakefield, unoxygenated, accompanied us on this little expedition, and oxygen at once proved its value, so easily did Bruce and I outpace them. On our return to Camp III., the delicate white mists floating in the sky above the North Col seemed to beckon to us to climb these snowy slopes and see what lay hid in the back of beyond. So two mornings later we started off for the North $\mathrm{Col}$ on another trial trip. In the afternoon we returned to Camp III. There had been a considerable amount of step-cutting, for fresh snow had fallen, compelling us to deviate from the usual route; but even so oxygen had made a brief Alpine ascent of what is otherwise a strenuous day's work. We took 3 hours up and 50 minutes down, with $3^{6}$ photographs taken en route.

On May 24, Captain Noel, Tejbir, Geoffrey Bruce, and I, all using oxygen, went up to the North Col (23,000 feet). Bent on a determined attack, we camped there for the night. Morning broke fine and clear though somewhat windy, and at 8 o'clock we sent off up the long snow slopes leading towards the north-east shoulder of Mount Everest, twelve porters carrying oxygen cylinders, provisions for one day, and camping gear. An hour and a half later, Bruce, Tejbir, and I followed, and, in spite of the fact that each bore a load of over 30 lbs., which was much more than the average weight carried by the porters, we overtook them at a height of about 24,500 feet. They greeted our arrival with their usual cheery, broad grins. But no longer did they regard oxygen as a foolish man's whim; one and all appreciated the advantages of what they naïvely chose to call "English air." Leaving them to follow, we went on, hoping to pitch our camp somewhere above 26,000 feet. But shortly after I o'clock the wind freshened up rather offensively, and it began to 
snow. Our altitude was 25,500 feet, some 500 feet below where we had hoped to camp, but we looked round immediately for a suitable camping site, as the porters had to return to the North Col that day, and persistence in proceeding further would have run them unjustifiably into danger. This I would under no circumstances do, for I felt responsible for these cheerful, smiling, willing men who looked up to their leader and placed in him the complete trust of little children. As it was, the margin of safety secured by pitching camp where we did instead of at a higher elevation was none too wide; for before the last porter had departed downwards the weather had become very threatening. A cheerful spot in which to find space to pitch a tent it was not; but though I climbed a couple of hundred feet or so further up the ridge, nothing more suitable was to be found. Remembering that a wind is felt more severely on the windward side of a ridge than on the crest, a possible position to the west of the ridge was negatived in favour of one on the very backbone. The leeside was bare of any possible camping-place within reasonable distance. Our porters arrived at 2 p.m., and at once all began to level off the little platform where the tent was soon pitched, on the very edge of the tremendous precipices falling away to the East Rongbuk and Main Rongbuk glaciers, over 4000 feet below. Within twenty minutes the porters were scurrying back down the broken rocky ridge towards the snow slopes leading to the North Col, singing as they went snatches of their native hillside ditties. What splendid men! Having seen the last man safely off, I looked to the security of the guy-ropes holding down the tent, and then joined Bruce and Tejbir inside. It was snowing hard. Tiny, minute spicules driven by the wind penetrated everywhere. It was bitterly cold, so we crawled into our sleeping-bags, and, gathering round us all available clothing, huddled up together as snugly as was possible. With the help of solidified spirit we melted snow and cooked a warm meal, which imparted some small measure of comfort to our chilled bodies. A really hot drink was not procurable, for the simple reason that at such an altitude water boils at so low a temperature that one can immerse the hand in it without fear of being scalded. Over a post prandium cigarette, Bruce and I discussed our prospects of success. Knowing that no man can put forward his best effort unless his confidence is an established fact, the trend of my contribution to the conversation was chiefly, "Of course, we shall get to the top." After sunset the storm rose to a gale, a term I use deliberately. Terrific gusts tore at our tent with such ferocity that the ground sheet with its human burden was frequently lifted up off the ground. On these occasions our combined efforts were needed to keep the tent down and prevent its being blown away. Although we had blocked up the few very small openings in the tent to the best of our powers, long before midnight we were all thickly covered in a fine frozen spindrift that somehow or other was blown in upon us, insinuating its way into sleeping-bags and clothing, there to cause acute discomfort. Sleep 


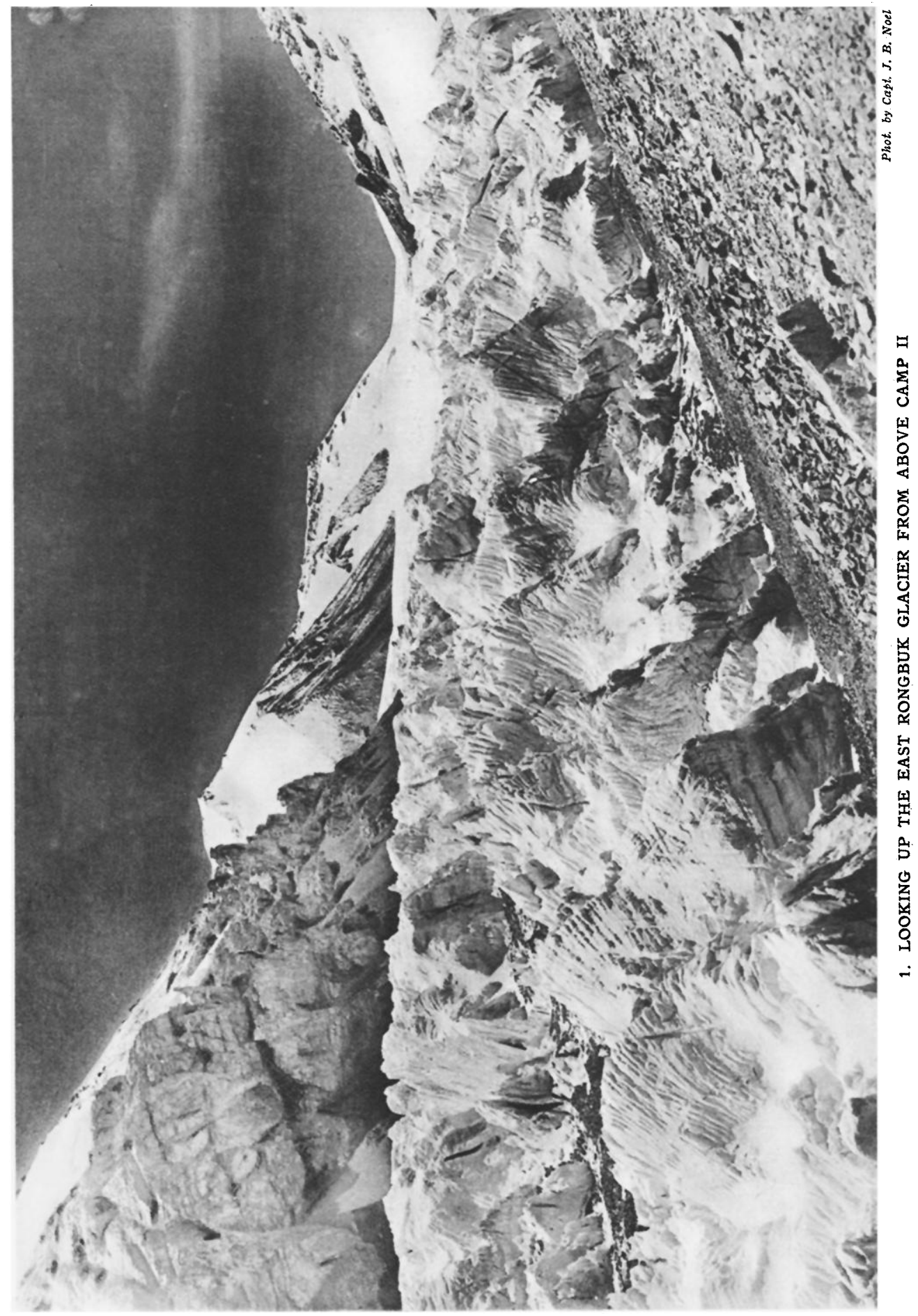

This content downloaded from 137.99.31.134 on Mon, 27 Jun 2016 05:06:46 UTC All use subject to http://about.jstor.org/terms 


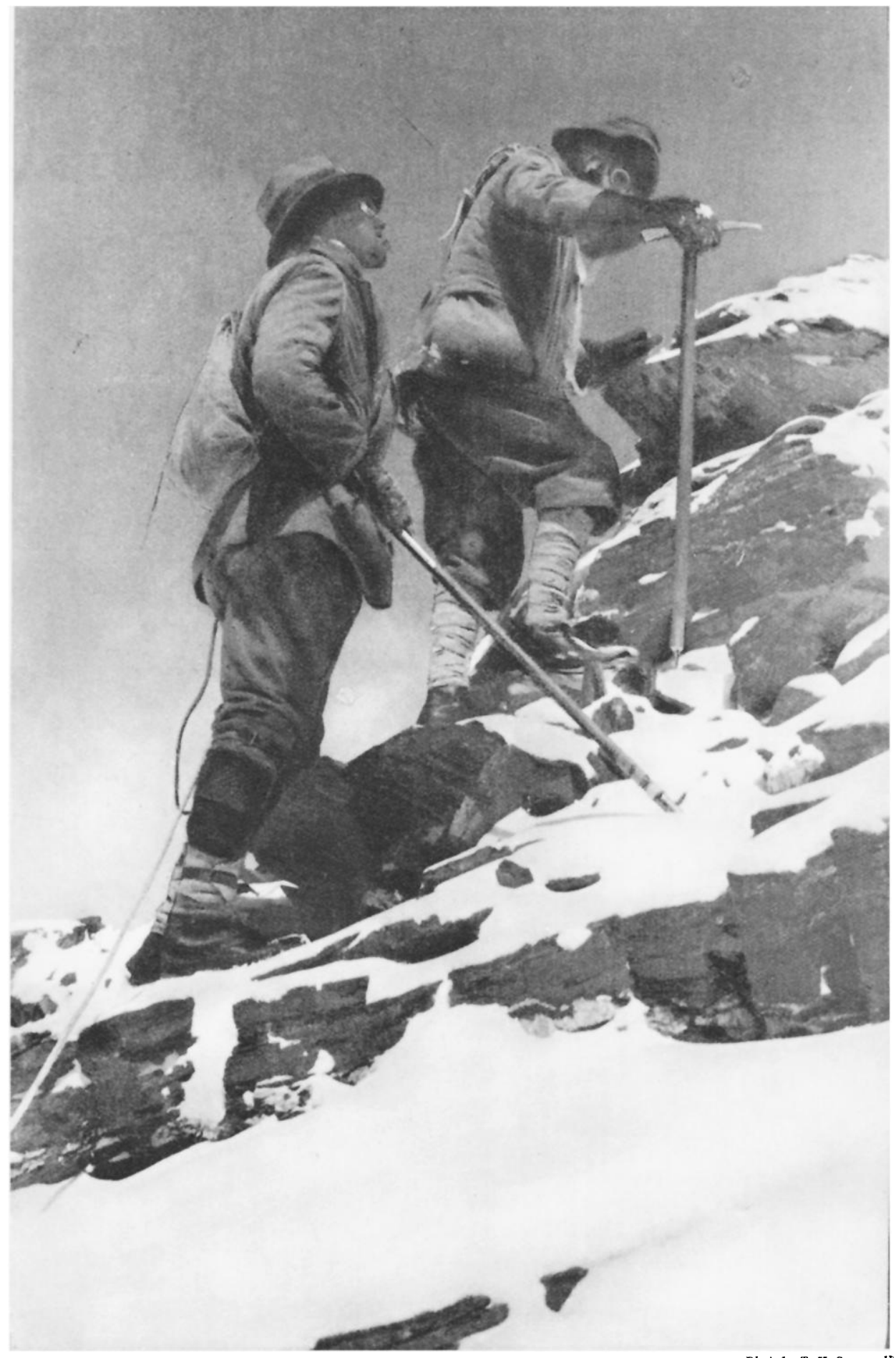

2. MALLORY AND NORTON APPROACHING THEIR HIGHEST POINT $(26,985$ FEET)

This content downloaded from 137.99.31.134 on Mon, 27 Jun 2016 05:06:46 UTC All use subject to http://about.jstor.org/terms 


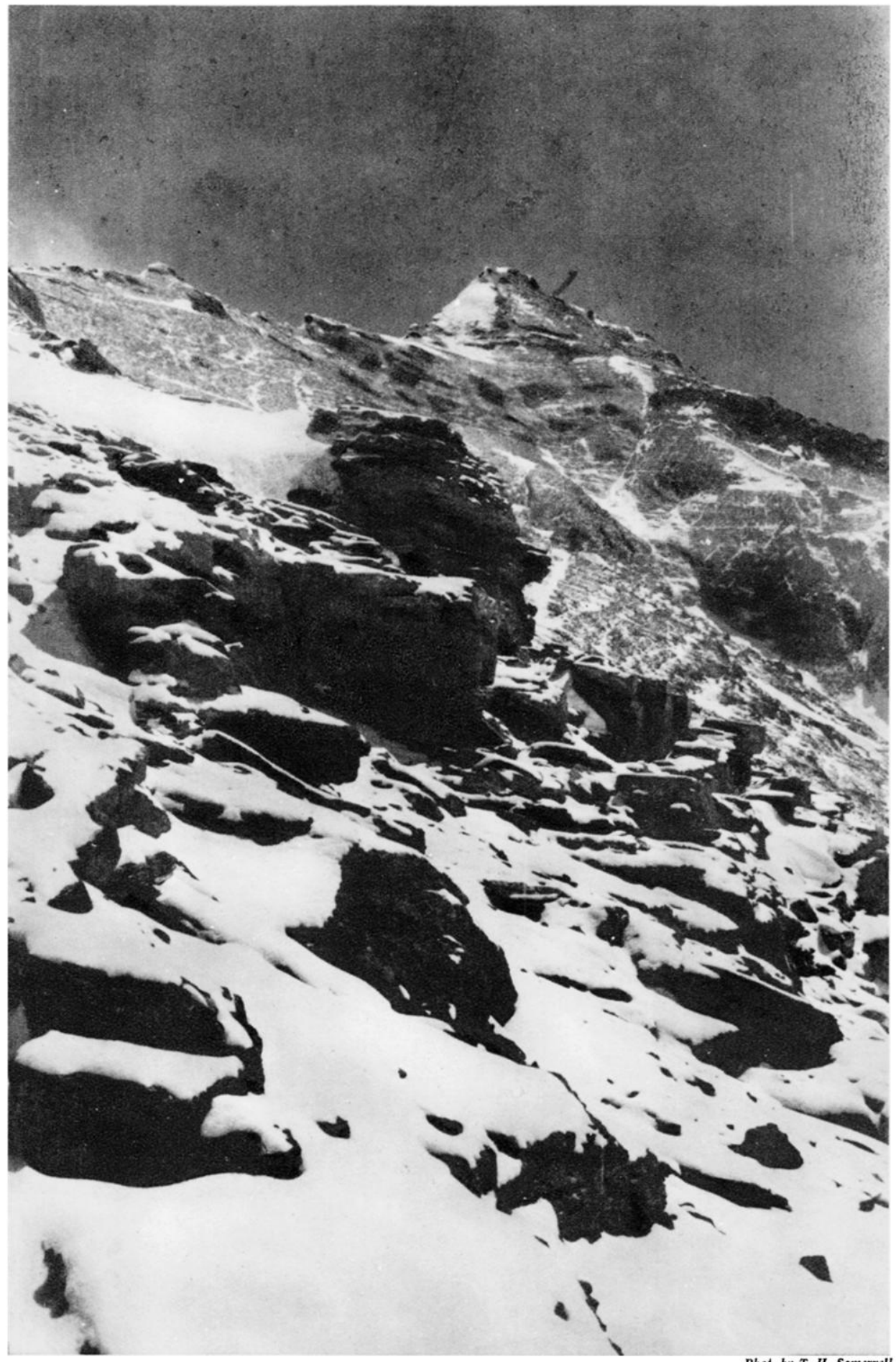

3. THE WAY TO THE SUMMIT FROM THE HIGHEST POINT OF THE FIRST CLIMB 


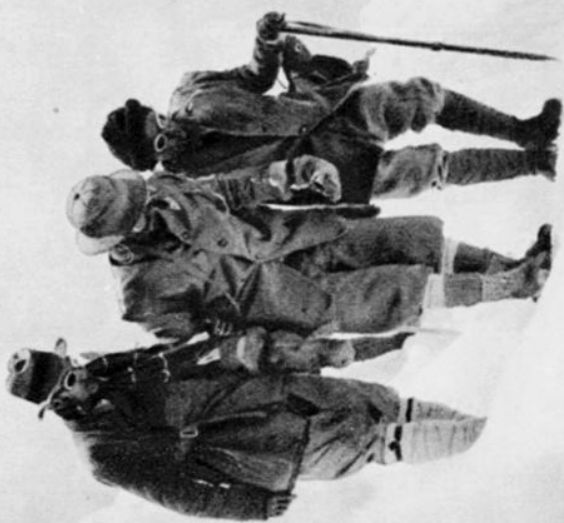




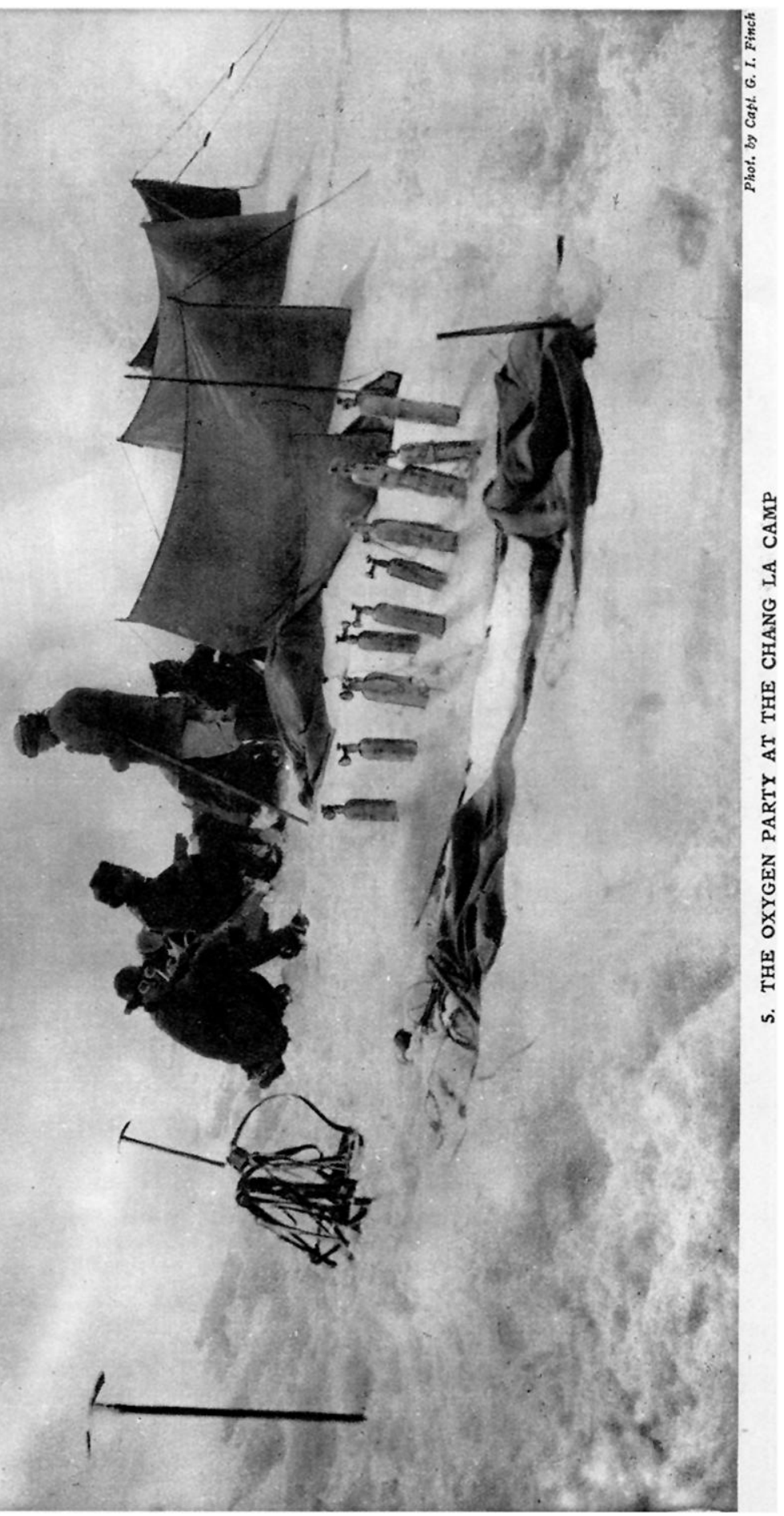

This content downloaded from 137.99.31.134 on Mon, 27 Jun 2016 05:06:46 UTC All use subject to http://about.jstor.org/terms 


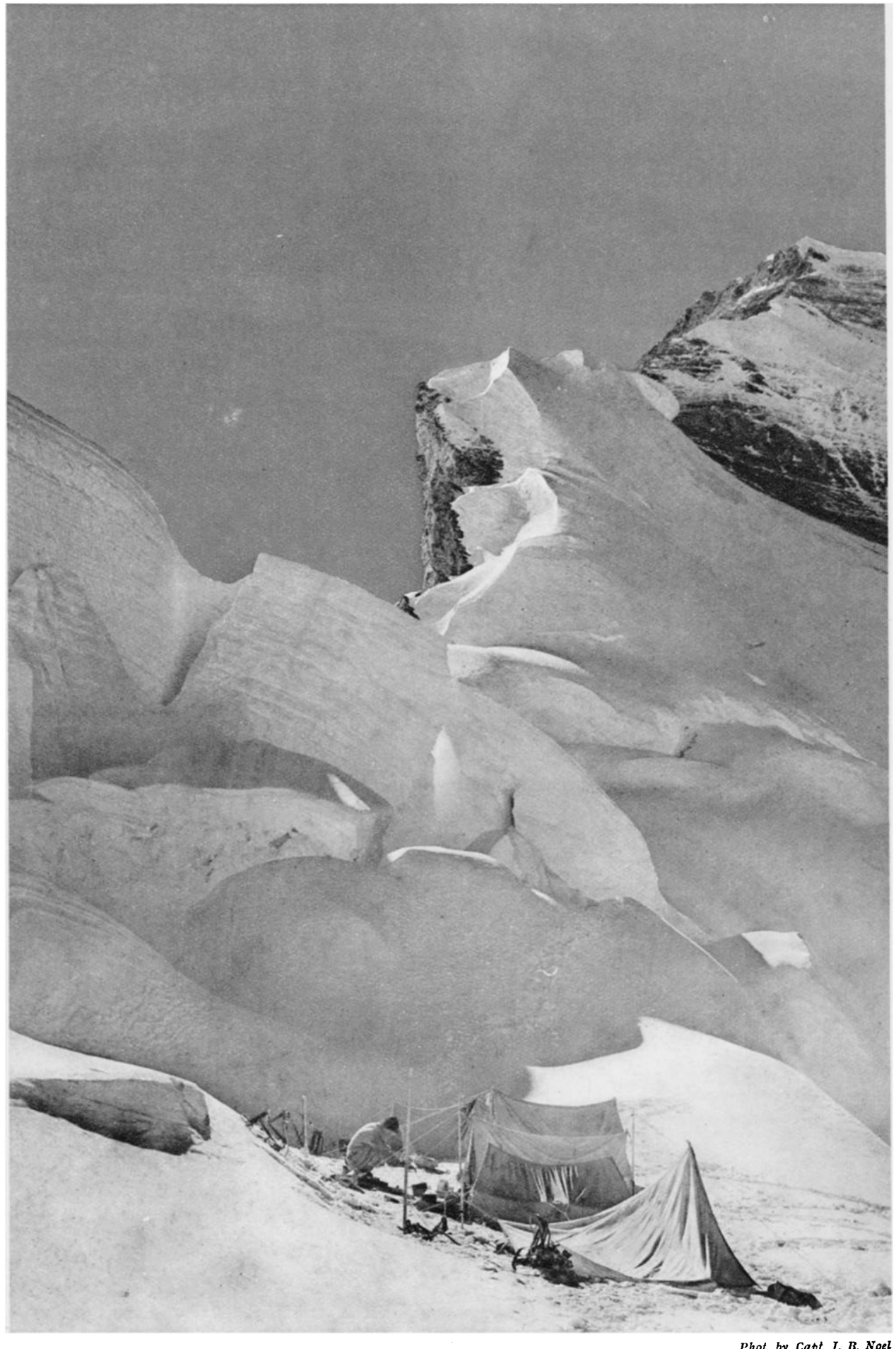

6. CHANGTSE FROM THE CAMP ON THE CHANG LA

Phot. by Capt. J. B. Noel

This content downloaded from 137.99.31.134 on Mon, 27 Jun 2016 05:06:46 UTC All use subject to http://about.jstor.org/terms 


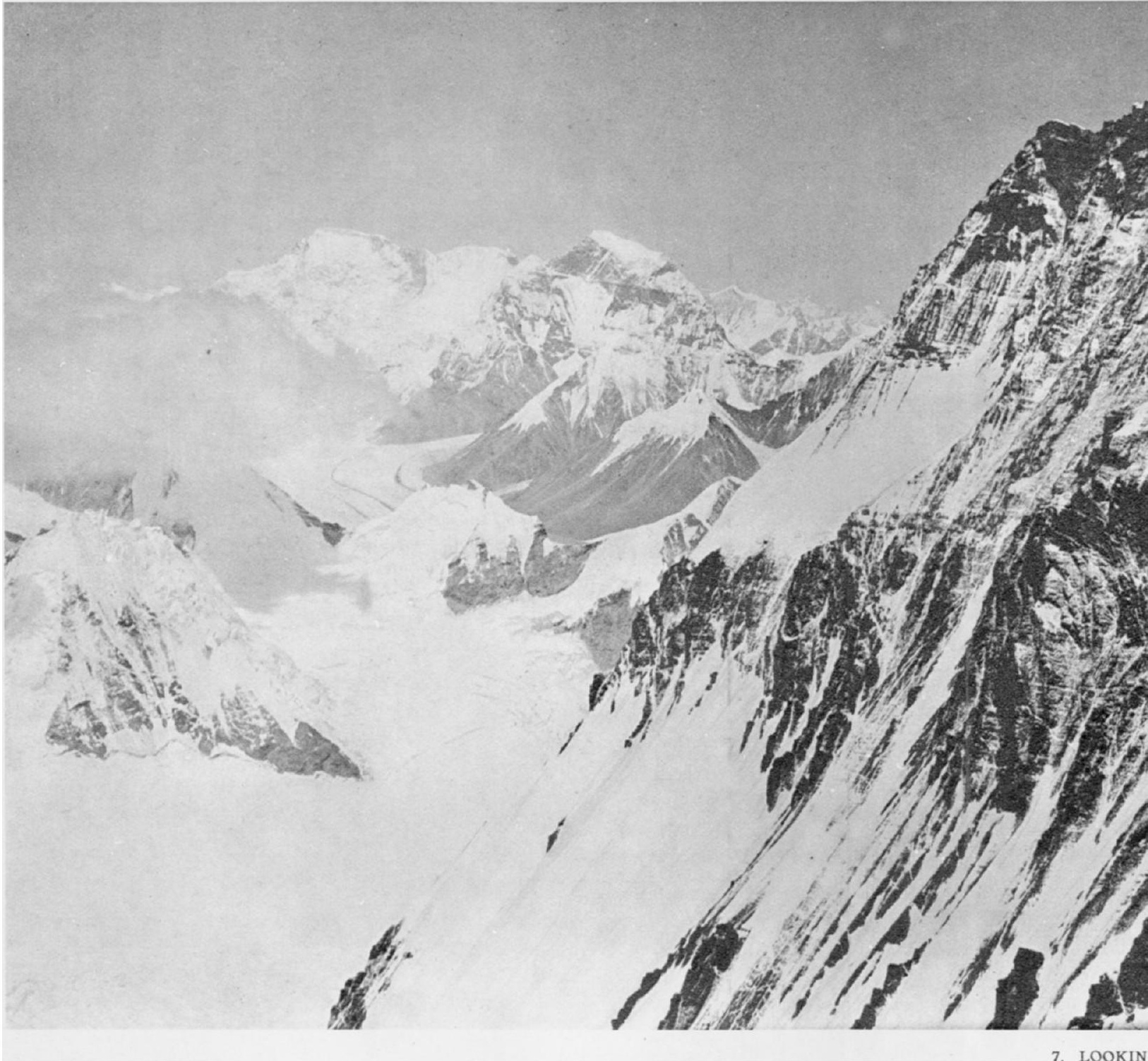

7. LOOKIN

This content downloaded from 137.99.31.134 on Mon, 27 Jun 2016 05:06:46 UTC All use subject to http://about.jstor.org/terms 

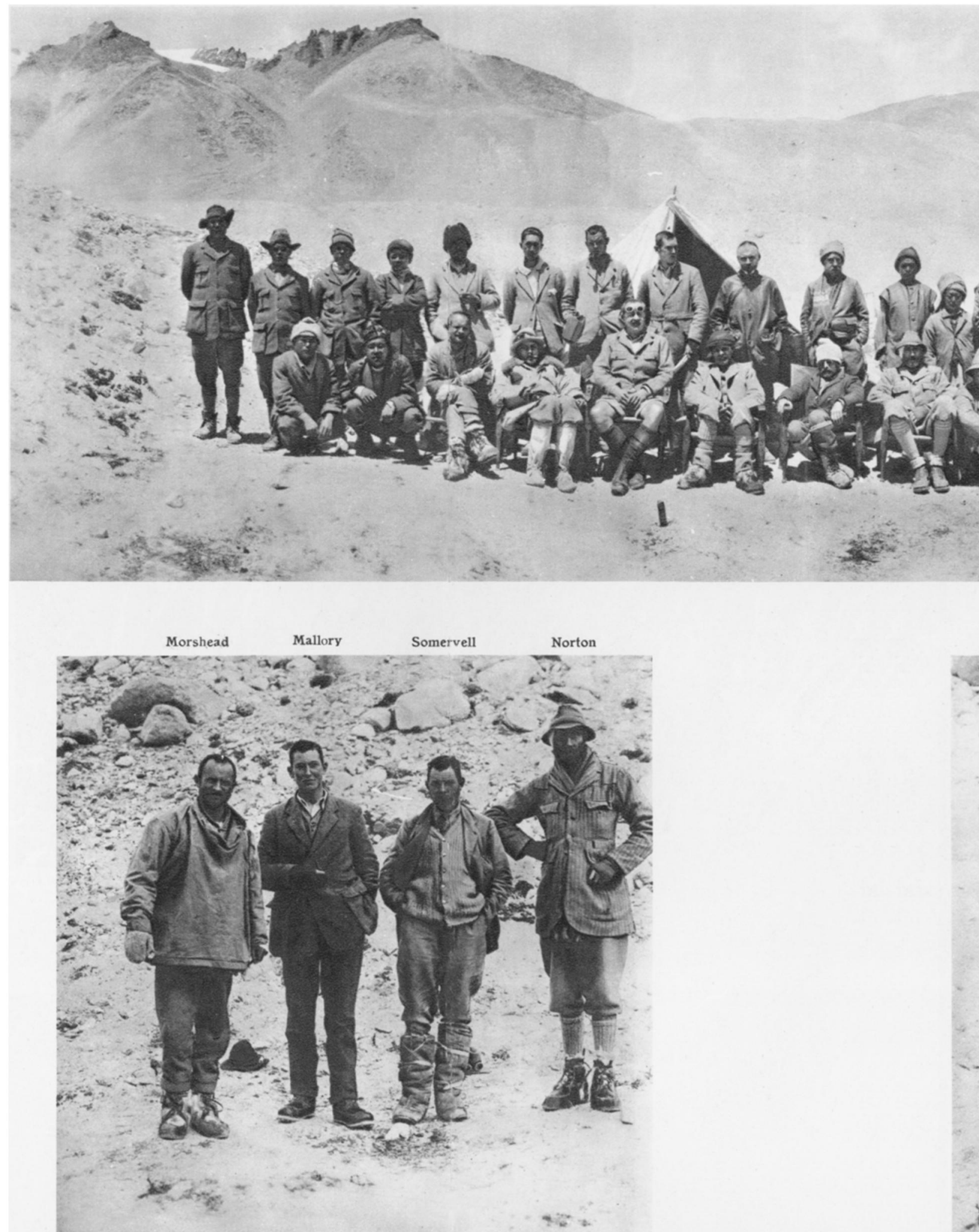

9. THE FIRST CLIMBING PARTY

Phot. by Capt. J. B. Noel 


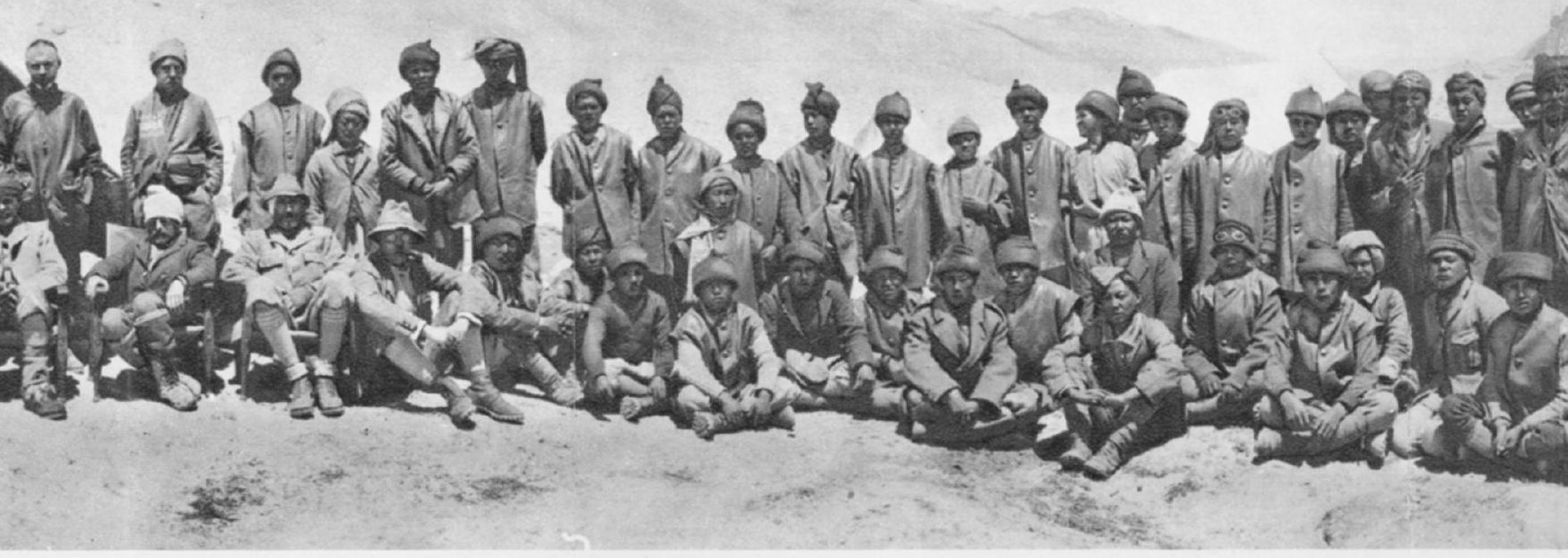

8. THE EXPEDITION AT THE BASE CAMP

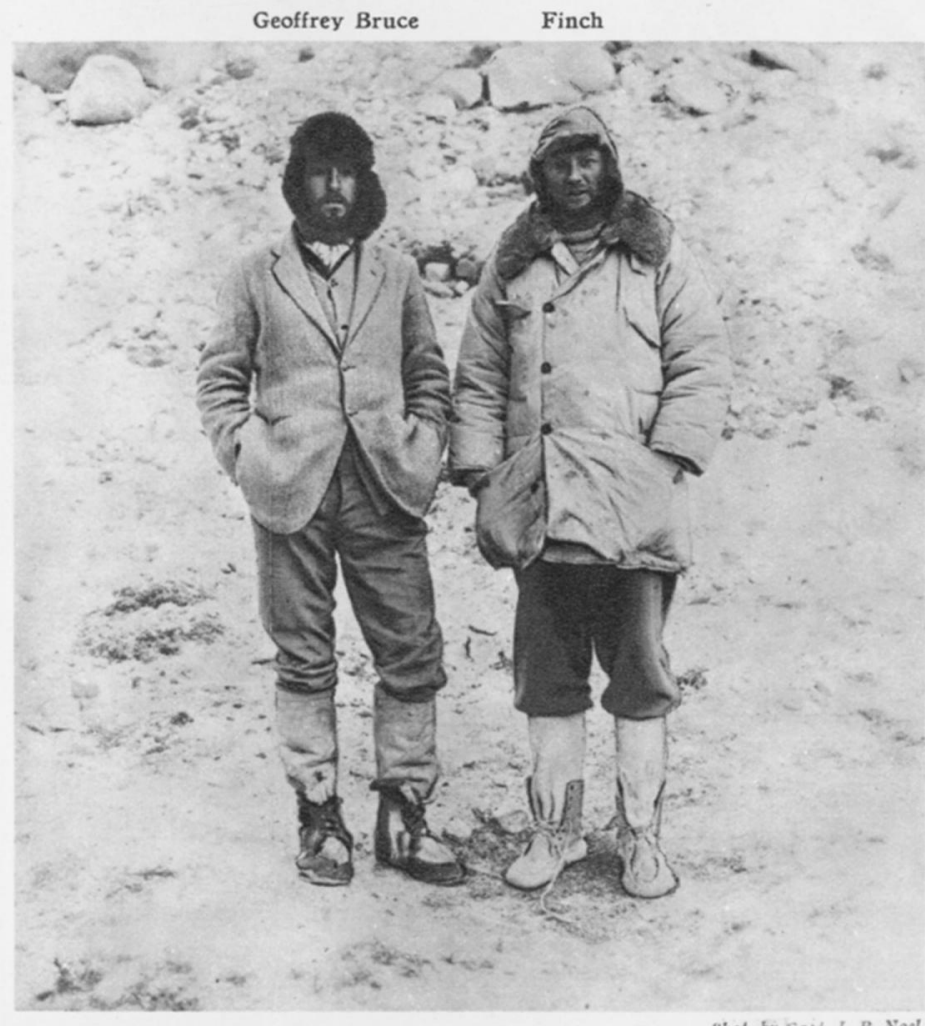

10. THE BRITISH MEMBERS OF THE SECOND CLIMBING PARTY

This content downloaded from 137.99.31.134 on Mon, 27 Jun 2016 05:06:46 UTC All use subject to http://about.jstor.org/terms 


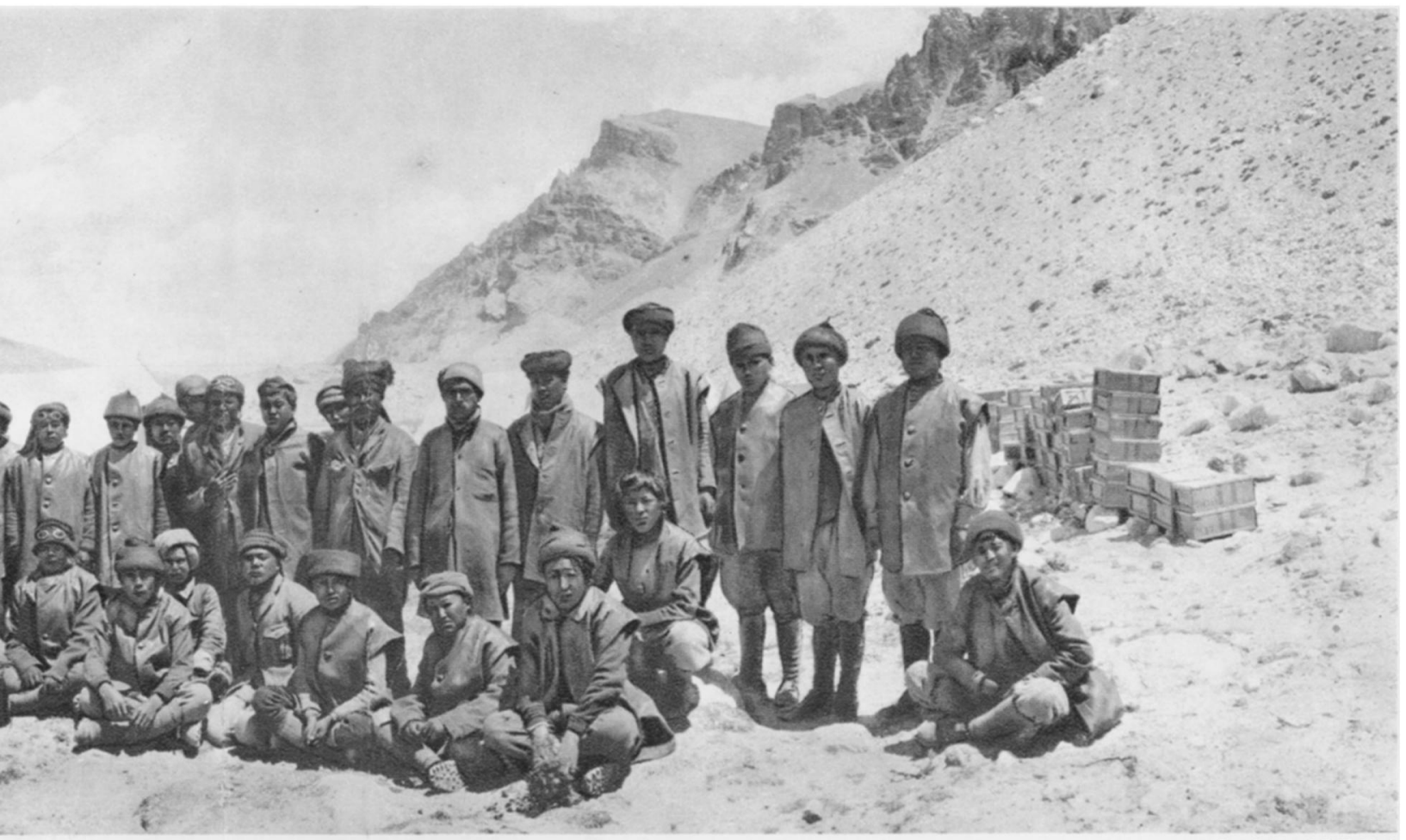

Phot, by Capt. J. B. Noet

Tejbir

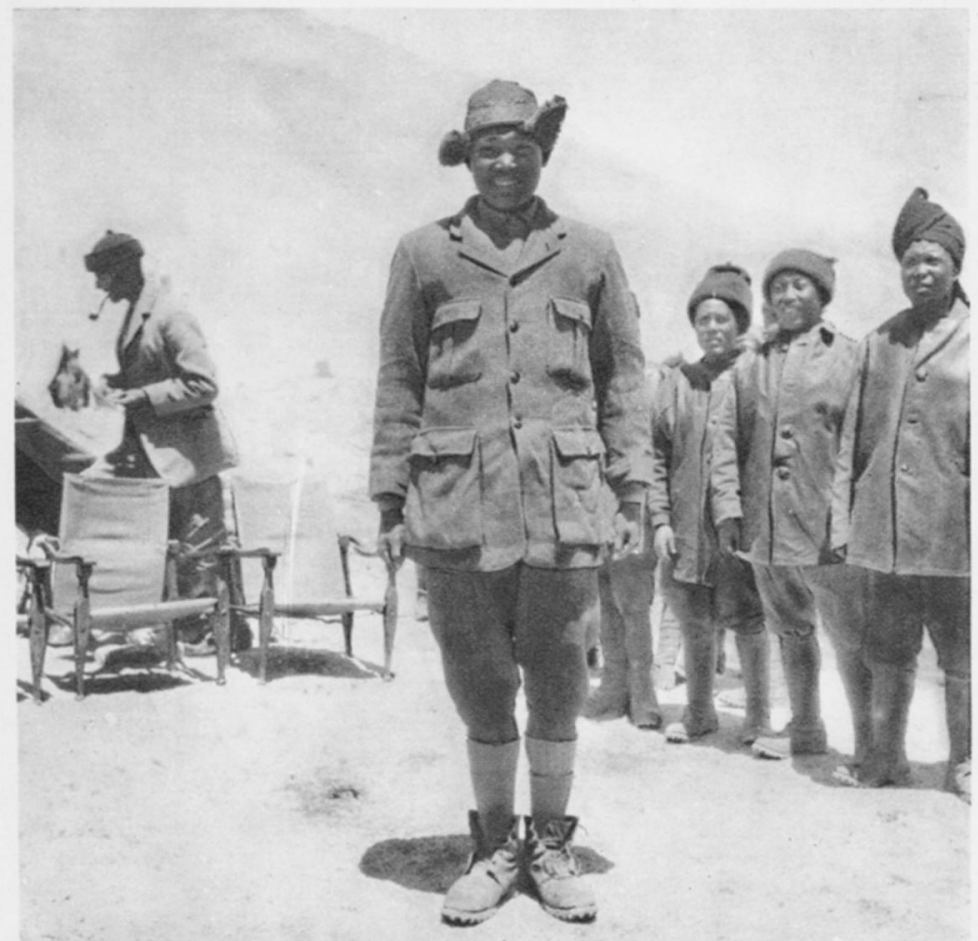

Phot, by Carh. G. I. Finch

11. TEJBIR THE GURKHA N.C.O. OF THE SECOND CLIMBING PARTY

This content downloaded from 137.99.31.134 on Mon, 27 Jun 2016 05:06:46 UTC All use subject to http://about.jstor.org/terms 


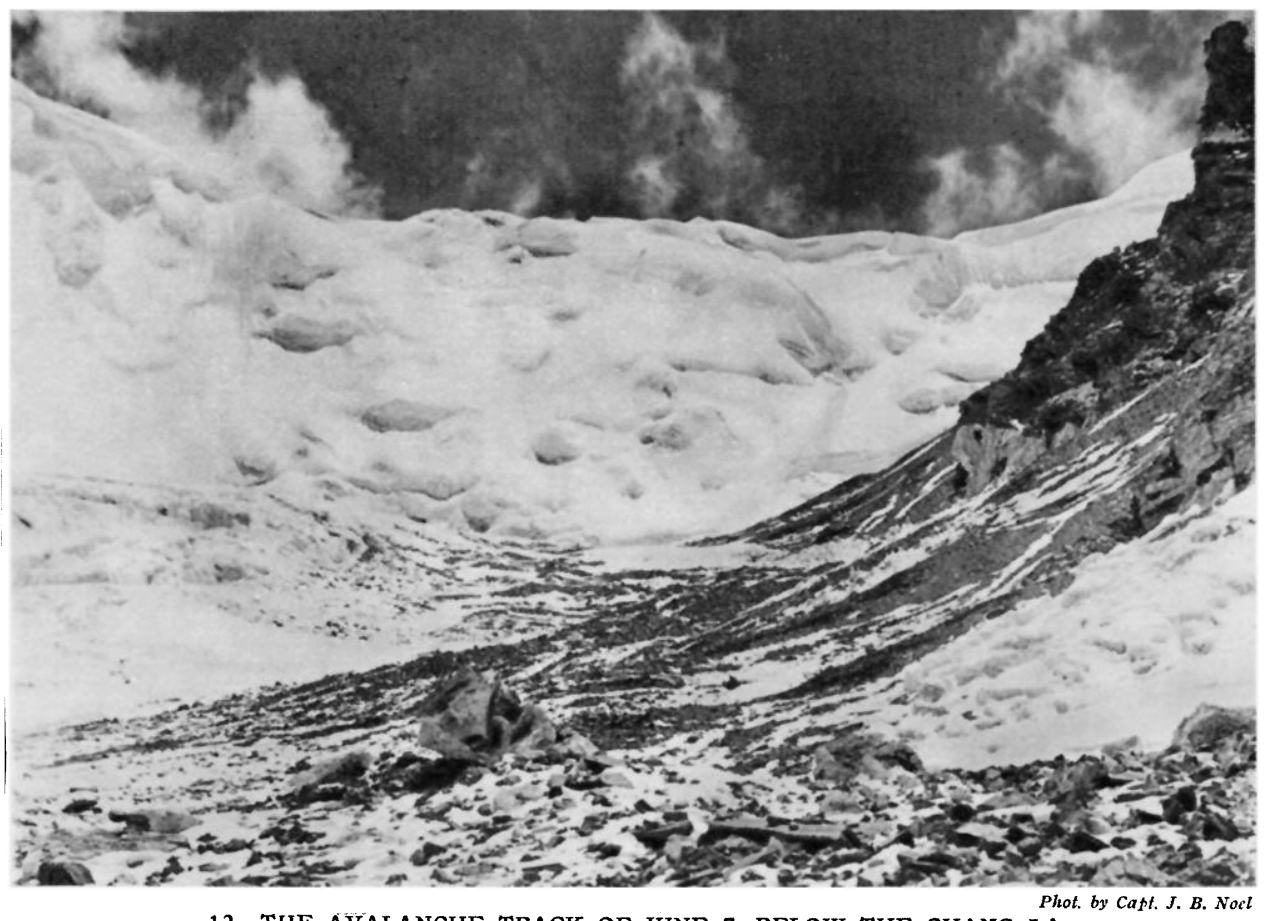

12. THE AVALANCHE TRACK OF JUNE 7, BELOW THE CHANG LA

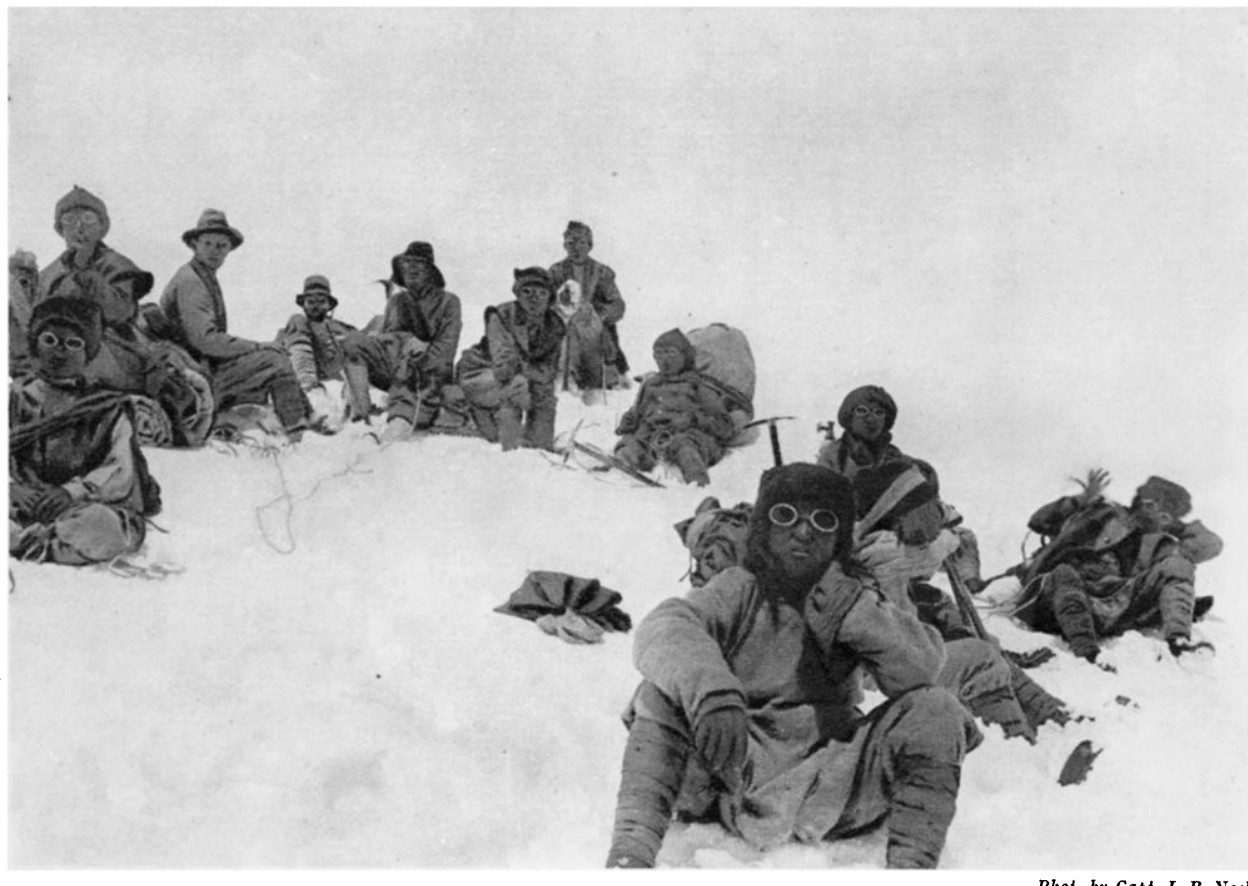

13. PARTY RESTING DURING THE ASCENT OF THE CHANG LA

This content downloaded from 137.99.31.134 on Mon, 27 Jun 2016 05:06:46 UTC All use subject to http://about.jstor.org/terms 


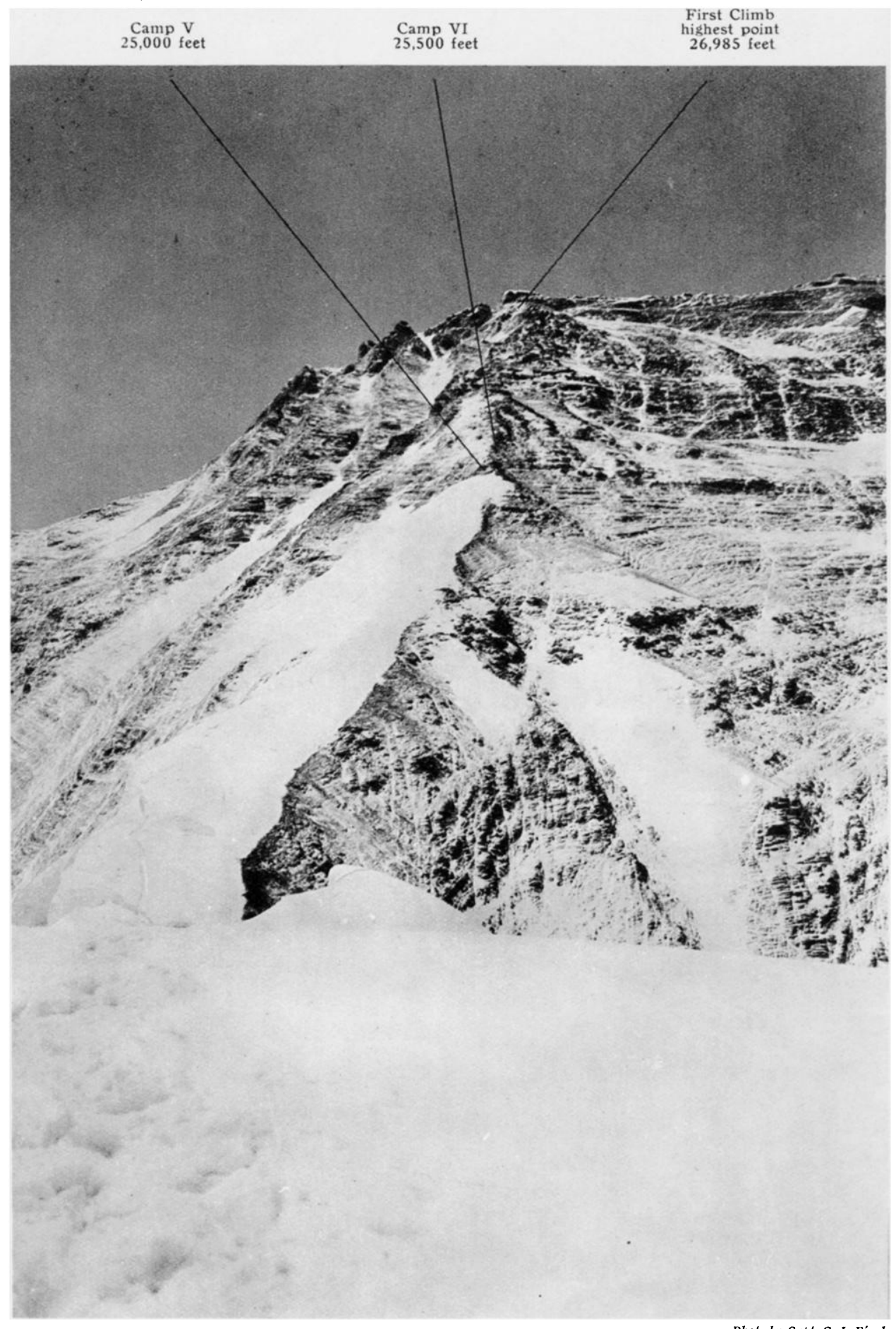

14. THE NORTH FACE OF SUMMIT OF MOUNT EVEREST FROM THE CHANG LA 


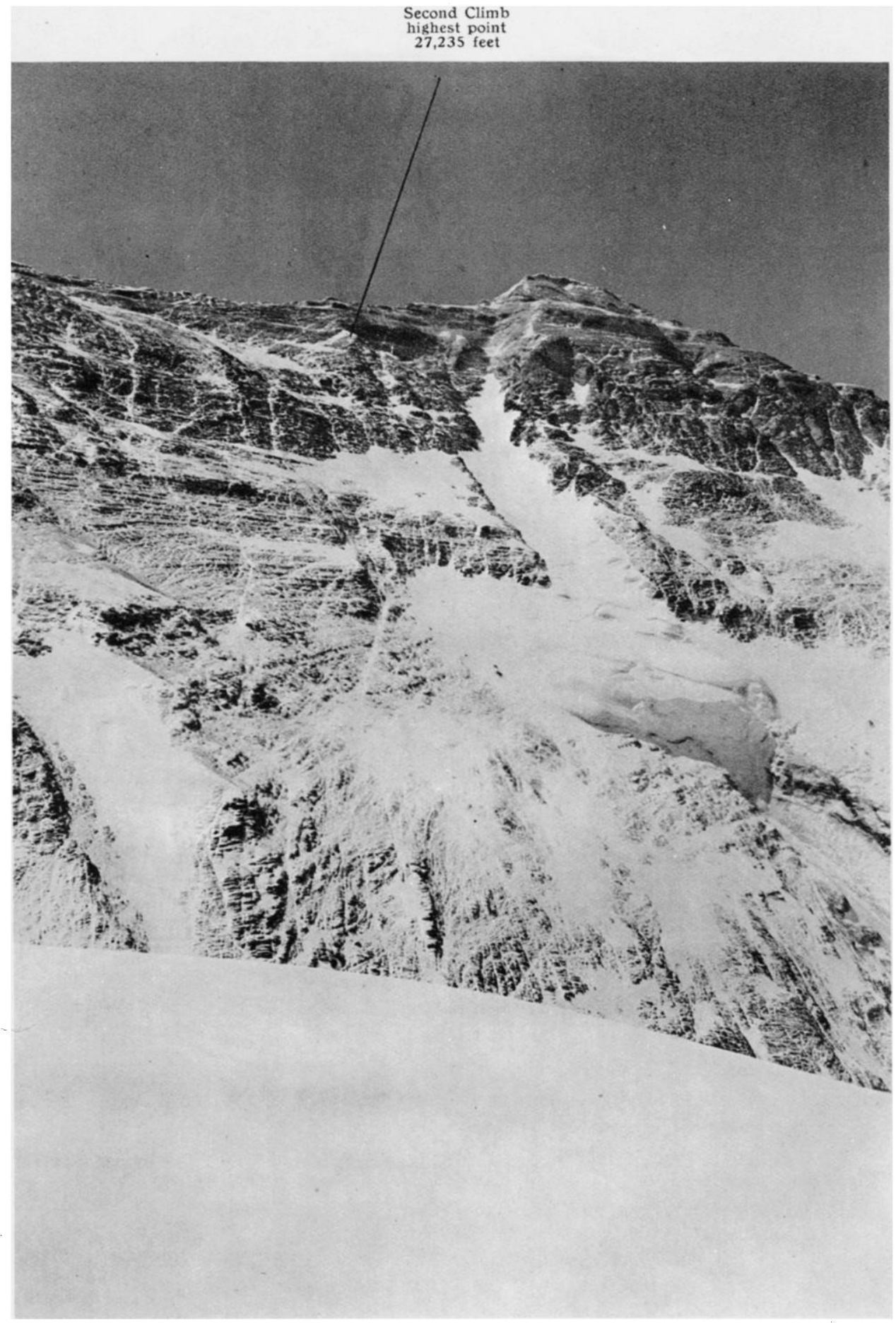

15. THE NORTHERN RIDGE OF MOUNT EVEREST FROM CHANG LA 


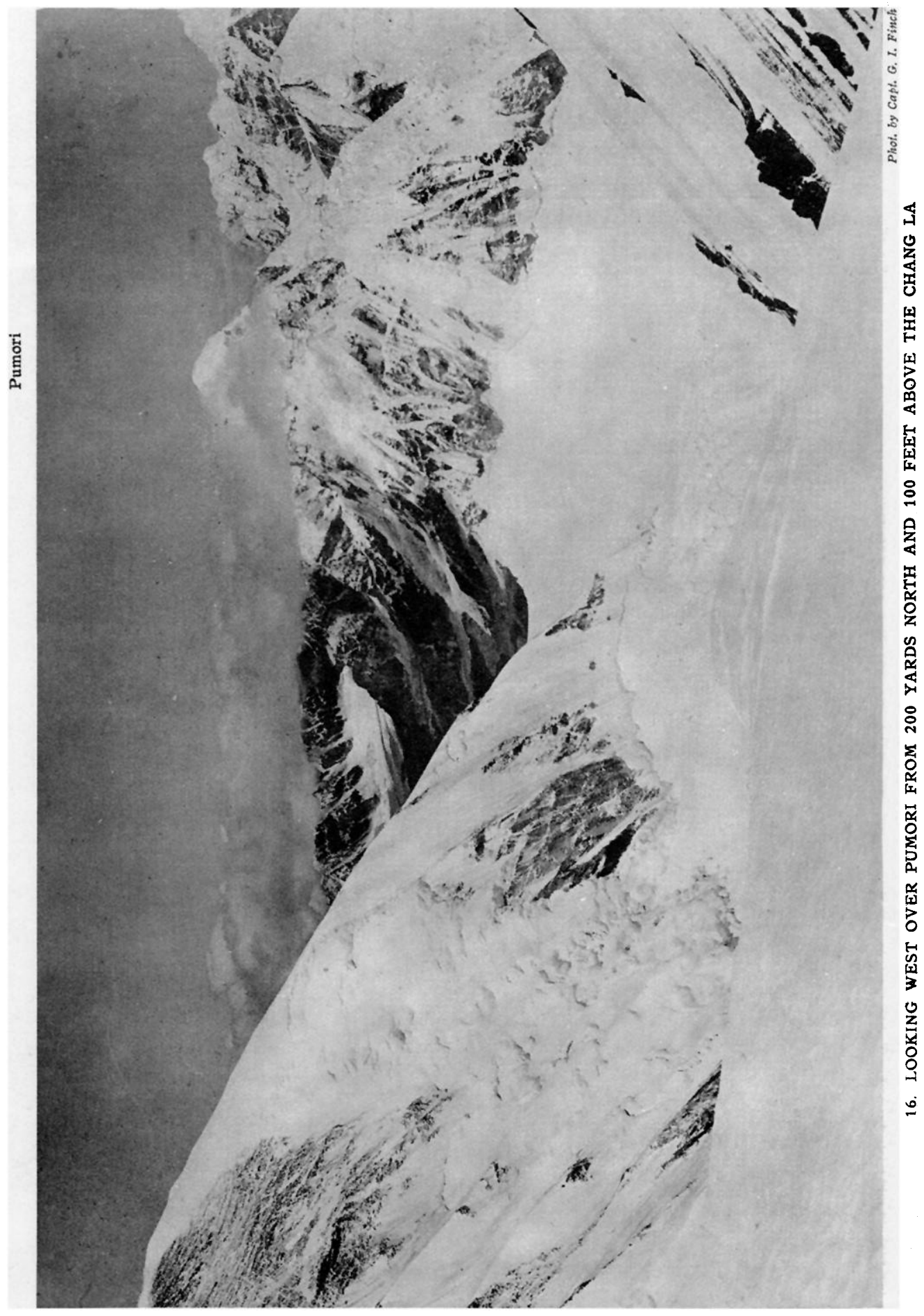


was out of the question. We dared not relax our vigilance, for ever and again all our strength was needed to hold the tent down and to keep the flaps of the door, stripped of their fastenings by a gust that had caught us unawares, from being torn open. We fought for our lives, realizing that once the wind got our little shelter into its ruthless grip it must inevitably be hurled with us inside it down on to the East Rongbuk glacier, thousands of feet below.

And what of my companions in the tent? To me who had certainly passed his novitiate in the hardships of mountaineering, the situation was more than alarming. About Tejbir I had no concern; he placed complete confidence in his sahibs, and the ready grin never left his face. But it was Bruce's first experience of mountaineering, and how the ordeal would affect him I did not know. I might have spared myself all anxiety. Throughout the whole adventure he bore himself in a manner that would have done credit to the finest of veteran mountaineers, and returned my confidence with a cheerfulness that rang too true to be counterfeit. By one o'clock on the morning of the 26 th the gale reached its maximum. The wild flapping of the canvas made a noise like that of machine-gun fire. So deafening was it that we could scarcely hear each other speak. Later, there came interludes of comparative lull, succeeded by bursts of storm more furious than ever. During such lulls we took it in turn to go outside to tighten up slackened guy-ropes, and also succeeded in tying down the tent more firmly with our Alpine rope. It was impossible to work in the open for more than three or four minutes at a stretch, so profound was the exhaustion induced by this brief exposure to the fierce cold wind. But with the Alpine rope taking some of the strain we enjoyed a sense of security which, though probably only illusory, allowed us all a few sorely needed moments of rest.

Dawn broke bleak and chill; the snow had ceased to fall, but the wind continued with unabated violence. Once more we had to take it in turns to venture without and tighten up the guy-ropes, and to try to build on the windward side of the tent a small wall of stones as an additional protection. The extreme exhaustion and the chill produced in the body as a result of each of these little excursions were sufficient to indicate that, until the gale had spent itself, there could be no hope of either advance or retreat. As the weary morning hours dragged on, we believed we could detect a slackening off in the storm. And I was thankful, for I was beginning quietly to wonder how much longer human beings could stand the strain. We prepared another meal. The dancing flames of the spirit stove caused me anxiety bordering on anguish lest the tent, a frail shelter between life and death, should catch fire. At noon the storm once more regained its strength and rose to unsurpassed fury. A great hole was cut by a stone in one side of the tent, and our situation thus unexpectedly became more desperate than ever. But Tejbir still smiled, and Bruce's cheerfulness was not found wanting; so we carried 
on, making the best of our predicament until, at I o'clock, the wind dropped suddenly from a blustering gale to nothing more than a stiff breeze. Now was the opportunity for retreat to the safety of the North Col camp. But I wanted to hang on and try our climb on the following day. Very cautiously and tentatively I broached my wish to Bruce, fearful lest the trying experience of the last twenty-four hours had undermined his keenness for further adventure. Once again I might have spared myself all anxiety. He jumped at the idea, and when our new plans were communicated to Tejbir, the only effect upon him was to broaden his already expansive grin.

It was a merry little party that gathered round to a scanty evening meal cooked with the last of our fuel. The meal was meagre for the simple reason that we had catered for only one day's short rations, and we were now very much on starvation diet. We had hardly settled down for another night when, about 6 p.m., voices were heard outside. Our unexpected visitors were porters who, anxious as to our safety, had left the North Col that afternoon when the storm subsided. With them they brought thermos flasks of hot beef-tea and tea provided by the thoughtful Noel. Having accepted these most gratefully, we sent the porters back without loss of time.

That night began critically. We were exhausted by our previous experiences and through lack of sufficient food. Tejbir's grin had lost some of its expanse. On the face of Geoffrey Bruce, courageously cheerful as ever, was a strained, drawn expression that I did not like. Provoked, perhaps, by my labours outside the tent, a dead, numbing cold was creeping up my limbs-a thing I had only once before felt, and to the seriousness of which I was fully alive. Something had to be done. Like an inspiration came the thought of trying the effect of oxygen. We hauled an apparatus and cylinders into the tent, and, giving it the air of a joke, we took doses all round. Tejbir took his medicine reluctantly, but with relief I saw his face brighten up. The effect on Bruce was visible in his rapid change of expression. A few minutes after the first breath, I felt the tingling sensation of returning life and warmth to my limbs. We connected up the apparatus in such a way that we could breathe a small quantity of oxygen throughout the night. The result was marvellous. We slept well and warmly. Whenever the tube delivering the gas fell out of Bruce's mouth as he slept, I could see him stir uneasily in the eerie greenish light of the moon as it filtered through the canvas. Then half unconsciously replacing the tube, he would fall once more into a peaceful slumber.

Before daybreak we were up, feeling fresh and fit, though terribly hungry. We proceeded to make ready for our climb. Putting on our boots was a struggle. Mine I had taken to bed with me, and a quarter of an hour's striving and tugging sufficed to get them on. But Bruce's and Tejbir's were frozen solid, and it took them the best part of an hour 
to mould them into shape by holding them over lighted candles. Shortly after six we assembled outside. Some little delay was incurred in arranging the rope and our loads, but at length at 6.30 a.m., soon after the first rays of the sun struck the tent, we shouldered our bundles and set off. What with cameras, thermos bottles, and oxygen apparatus, Bruce and I each carried well over $40 \mathrm{lbs}$. ; Tejbir with two extra cylinders of oxygen shouldered a burden of about 50 lbs. Our scheme of attack was to take Tejbir with us as far as the north-east shoulder, there to relieve him of his load and send him back. The weather was clear. The only clouds seemed so far off as to presage no evil, and the breeze, though intensely cold, was bearable. But it soon freshened up, and before we had gone more than a few hundred feet the cold began to have its effect on Tejbir's sturdy constitution, and he showed signs of wavering. Bruce's eloquent flow of Gurumuki, however, managed to boost him up to an altitude of 26,000 feet. There he collapsed entirely, sinking face downwards on to the rocks and crushing beneath him the delicate instruments of his oxygen apparatus. I stormed at him for thus maltreating it, while Bruce exhorted him for the honour of his regiment to struggle on; but it was all in vain. Tejbir had done his best; and he has every right to be proud of the fact that he has climbed to a far greater height than any other native. We pulled him off his apparatus and, relieving him of some cylinders, cheered him up sufficiently to start him with enough oxygen on his way back to the high camp, there to await our return. We had no compunction about letting him go alone, for the ground was easy and he could not lose his way, the tent being in full view below.

After seeing him safely off and making good progress, we loaded up Tejbir's cylinders, and, in view of the easy nature of the climbing, mutually agreed to dispense with the rope, and thus enable ourselves to proceed more rapidly. Climbing not very steep and quite easy rocks, and passing two almost level places affording ample room for some future high camp, we gained an altitude of 26,500 feet. By this time, however, the wind, which had been steadily rising, had acquired such force that I considered it necessary to leave the ridge and continue our ascent by traversing out across the great northern face of Mount Everest, hoping by so doing to find more shelter from the icy blasts. It was not easy to come to this decision, because I saw that between us and the shoulder the climbing was all plain sailing and presented no outstanding difficulty. Leaving the ridge, we began to work out into the face. For the first few yards the going was sufficiently straightforward, but presently the general angle became much steeper, and our trials were accentuated by the fact that the stratification of the rocks was such that they shelved outward and downward, making the securing of adequate footholds difficult. We did not rope, however. I knew that the longer we remained unroped, the more time we should save-a consideration of vital importance. But as I led out over these steeply sloping, evilly smooth slabs, I carefully 
watched Bruce to see how he would tackle the formidable task with which he was confronted on this his first mountaineering expedition. He did his work splendidly and followed steadily and confidently, as if he were quite an old hand at the game. Sometimes the slabs gave piace to snow - treacherous, powdery stuff, with a thin, hard, deceptive crust that gave the appearance of compactness. Little reliance could be placed upon it, and it had to be treated with great care. And sometimes we found ourselves crossing steep slopes of scree that yielded and shifted downwards with every tread. Very occasionally in the midst of our exacting work we were forced to indulge in a brief rest in order to replace an empty cylinder of oxygen by a full one. The empty ones were thrown away, and as each bumped its way over the precipice and the good steel clanged like a church bell at each impact, we laughed aloud at the thought that "There goes another 5 lbs. off our backs." Since leaving the ridge we had not made much height although we seemed to be getting so near our goal. Now and then we consulted the aneroid barometer and its readings encouraged us on. 27,000 feet; then we gave up traversing and began to climb diagonally upwards towards a point on the lofty north-east ridge, midway between the shoulder and the summit. Soon afterwards an accident put Bruce's oxygen apparatus out of action. He was some 20 feet below me, but struggled gallantly upwards as I went to meet him, and, after connecting him on to my apparatus and so renewing his supply of oxygen, we soon traced the trouble and effected a satisfactory repair. The barometer here recorded a height of 27,300 feet. The highest mountain visible was Cho Uyo, which is just short of 27,000 feet. We were well above it, and could look across it into the dense clouds beyond. The great west peak of Mount Everest, one of the most beautiful sights to be seen from down in the Rongbuk valley, was hidden, but we knew that our standpoint was nearly 2000 feet above it. Everest itself was the only mountain-top which we could see without turning our gaze downwards. We could look across into clouds which lay at some undefined distance behind the north-east shoulder, a clear indication that we were only a little, if any, below its level. Pumori, an imposing ice-bound pyramid, 23,000 feet high, I sought at first in vain. So far were we above it that it had sunk into an insignificant little ice hump by the side of the Rongbuk glacier. Most of the other landmarks were blotted out by masses of ominous yellow-hued clouds swept from the west in the wake of an angry storm-wind. The point we reached is unmistakable even from afar. We were standing on a little rocky ledge, just inside an inverted $\mathrm{V}$ of snow, immediately below the great belt of reddish-yellow rock which cleaves its way almost horizontally through the otherwise greenish-black slabs of the mountain. Though I 700 feet below, we were well within half a mile of the summit, so close indeed that we could distinguish individual stones on a little patch of scree lying just underneath the highest point. 
Ours were truly the tortures of Tantalus; for, weak from hunger and exhausted by that nightmare struggle for life in our high camp, we were in no fit condition to proceed. Indeed, I knew that if we were to persist in climbing on, even if only for another 500 feet, we should not both get back alive. The decision to retreat once taken, no time was lost, and, fearing lest another accidental interruption in the oxygen supply might lead to a slip on the part of either of us, we roped together. It was midday. At first we returned in our tracks, but later found better going by aiming to strike the ridge between the north-east shoulder and the North Col at a point above where we had left it in the morning. Progress was more rapid, though great caution was still necessary. Shortly after 2 p.m., we struck the ridge and there reduced our burdens to a minimum by dumping four oxygen cylinders. The place will be easily recognized by future explorers; those four cylinders are perched against a rock at the head of the one and only large snow-filled couloir running right up from the head of the East Rongbuk glacier to the ridge. The clear weather was gone. We plunged down the easy broken rocks through thick mists driven past us from the west by a violent wind. For one small mercy we were thankful-no snow fell. We reached our high camp in barely half an hour, and such are the vagaries of Mount Everest's moods that in this short time the wind had practically dropped. Tejbir lay snugly wrapped up in all three sleeping-bags, sleeping the deep sleep of exhaustion. Hearing the voices of the porters on their way up to bring down our kit, we woke him up, telling him to await their arrival and to go down with them. Bruce and I then proceeded on our way, met the ascending porters and passed on, greatly cheered by their bright welcomes and encouraging smiles. But the long descent, coming as it did on the top of a hard day's work, soon began to find out our weakness. We were deplorably tired, and could no longer move ahead with our accustomed vigour. Knees did not always bend and unbend as required. At times they gave way altogether and forced us, staggering, to sit down. But eventually we reached the broken snows of the North Col, and arrived in camp there at 4 p.m. A craving for food, to the lack of which our weakness was mainly due, was all that animated us. Hot tea and a tin of spaghetti were soon forthcoming, and even this little nourishment refreshed us and renewed our strength to such an extent that three-quarters of an hour later we were ready to set off for Camp III. An invaluable addition to our little party was Captain Noel, the indefatigable photographer of the expedition, who had already spent four days and three nights on the North Col. He formed our rearguard and nursed us safely down the steep snow and ice slopes on to the almost level basin of the glacier below. Before 5.30 p.m., only forty minutes after leaving the col, we reached Camp III. Since midday, from our highest point we had descended over 6000 feet; but we were quite finished. 
That evening we dined well. Four whole quails truffled in pâté-defoie gras, followed by nine sausages, left me asking for more. The last I remember of that long day was going to sleep, warm in the depths of our wonderful sleeping-bag, with the remains of a tin of toffee tucked away in the crook of my elbow.

Next morning showed that Bruce's feet were sorely frostbitten. I had practically escaped; but the cold had penetrated the half-inch-thick soles of my boots and three pairs of heavy woollen socks, and four small patches of frostbite hampered me at first in my efforts to walk. Bruce was piled on to a sledge, and I journeyed with him as his fellowpassenger. Willing porters dragged us down until the surface of the glacier became so rough as to impose too great a strain on our slender conveyance with its double burden.

Our attack upon Mount Everest had failed. The great mountain with its formidable array of defensive weapons had won; but if the body had suffered, the spirit was still whole. Reaching a point whence we obtained our last close view of the great unconquered Goddess Mother of the Snows, Geoffrey Bruce bade his somewhat irreverent adieux with "Just you wait, old thing, you'll be for it soon!"-words that still are expressive of my own sentiments.

\section{THE MOUNT EVEREST PHOTOGRAPHS}

THE photogravures from this year's photographs published in the October Fournal were concerned mainly, though not entirely, with the journey from Darjeeling to the Base in the Rongbuk valley below the snout of the main glacier. In this number, which contains the account of the two record-breaking high climbs, we publish a second series illustrating more particularly the alpine climbing and the personnel of the expedition.

Plate I shows the east Rongbuk glacier above Camp II., looking up to the south-east. Last year the climbing party came over the Lhakpa $\mathrm{La}$ at 22,500 feet, lying somewhere behind the hill in the centre of the picture, and crossed the smooth upper glacier to the Chang La. The route was not difficult, and the Kharta valley was a much more favourable camping-ground than the Rongbuk. But there was always the danger of a 22,500-foot pass in the line of communication and retreat; whence the preference this year for the East Rongbuk route, despite the frightful séracs and the great medial trench described by Colonel Strutt, and very well shown in this picture. The route lies along the foot of the moraine slope to a point near the right-hand edge of the picture, and then strikes out through the séracs to the centre.

Plates 2 and 3 are enlarged from two V.P.K. negatives made by Mr. Somervell. They are taken much higher than any photographs were ever before made on the Earth's surface, and they are the only photographs 


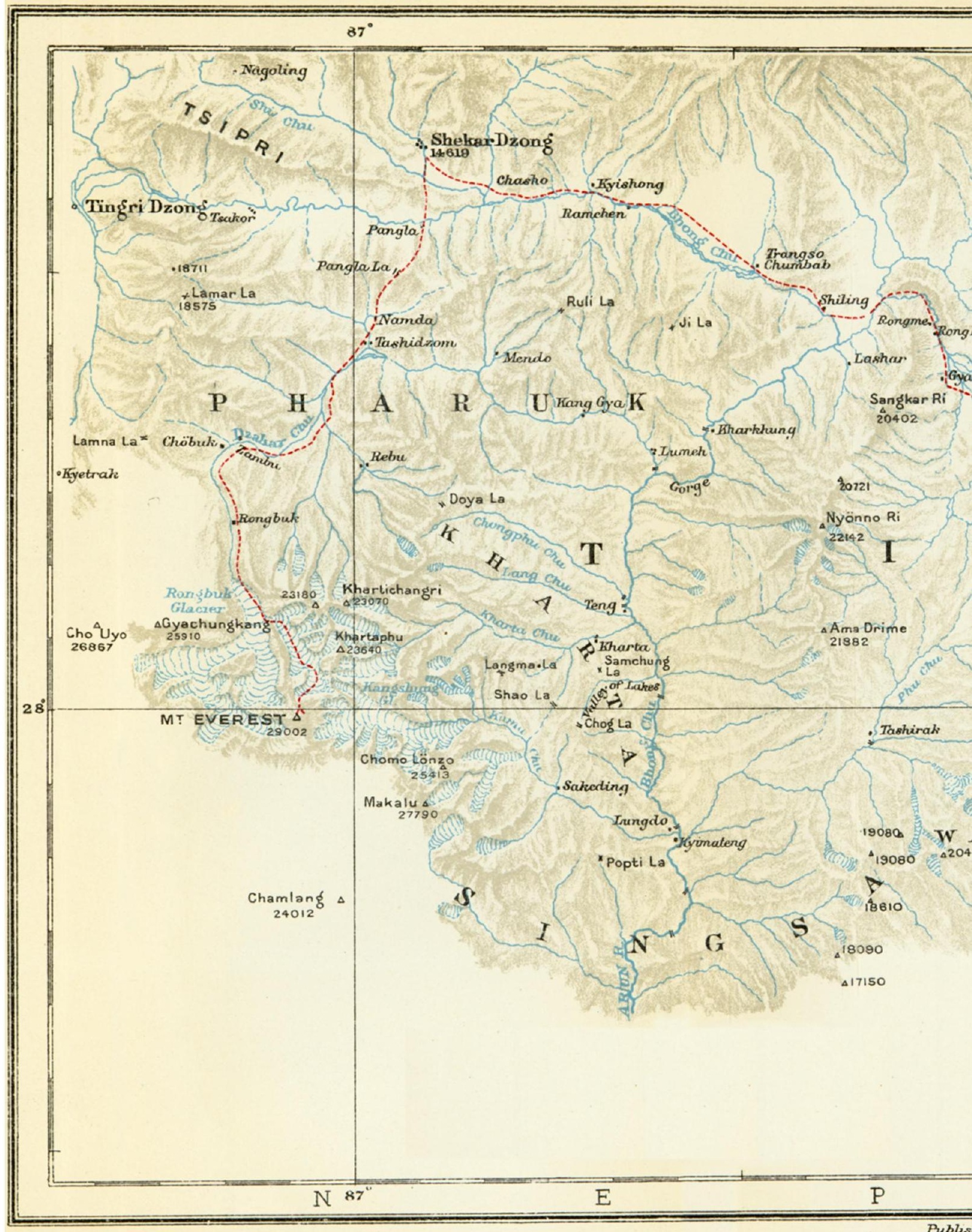




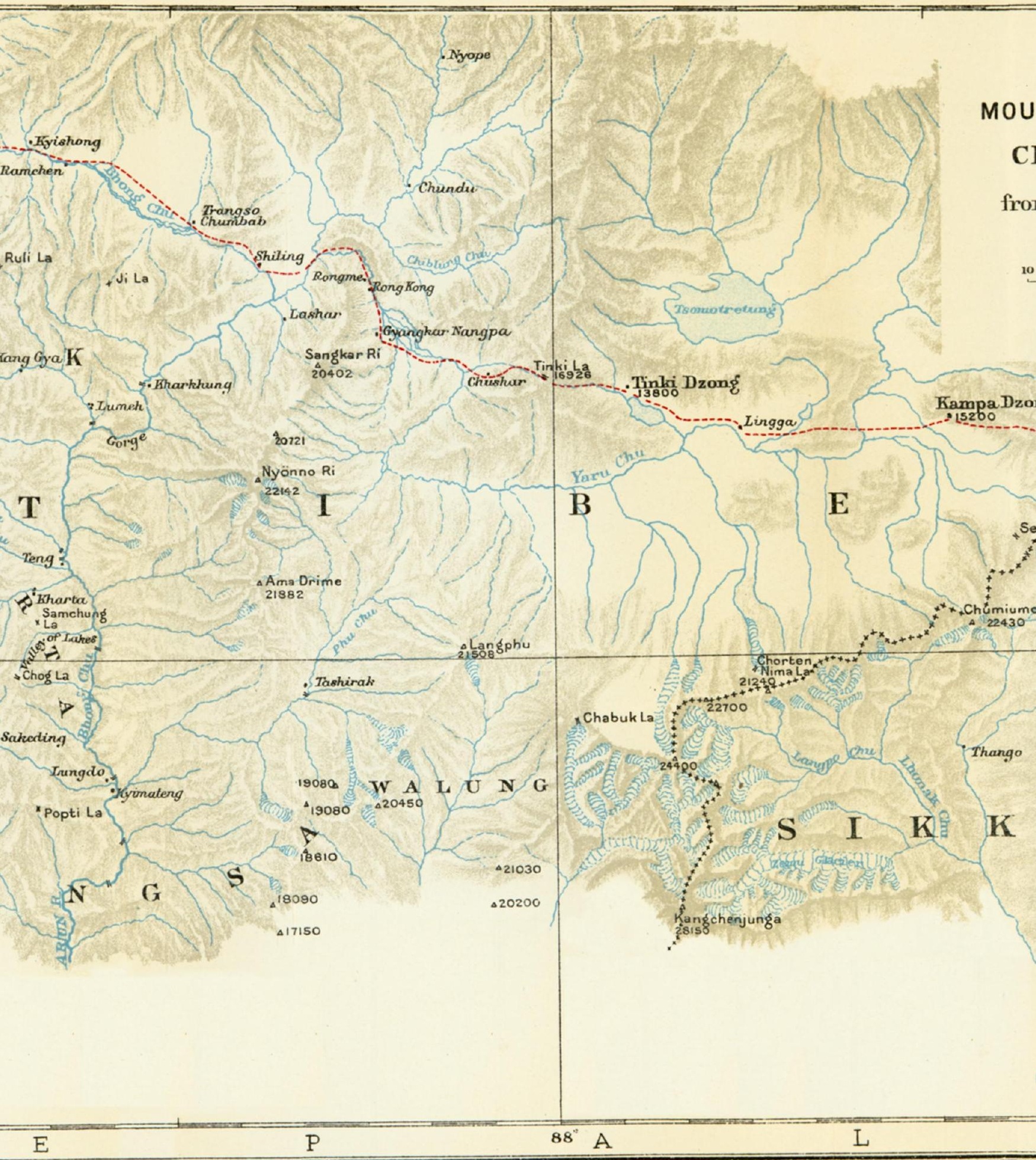

Publeshed by the Royal Geographical Society. 
The Route of the

\section{MOUNT EVEREST EXPEDITION 1922}

\section{CHUMBI TO M? EVEREST}

from the Maps of the 1921 Expedition.

Scale $1 / 750,000$ or 1 Inch - $11 \cdot 84$ Stat. Miles

10

10 20

Route of the Expedition ...... Pass=

Heights in feet.

Tinki Dzong

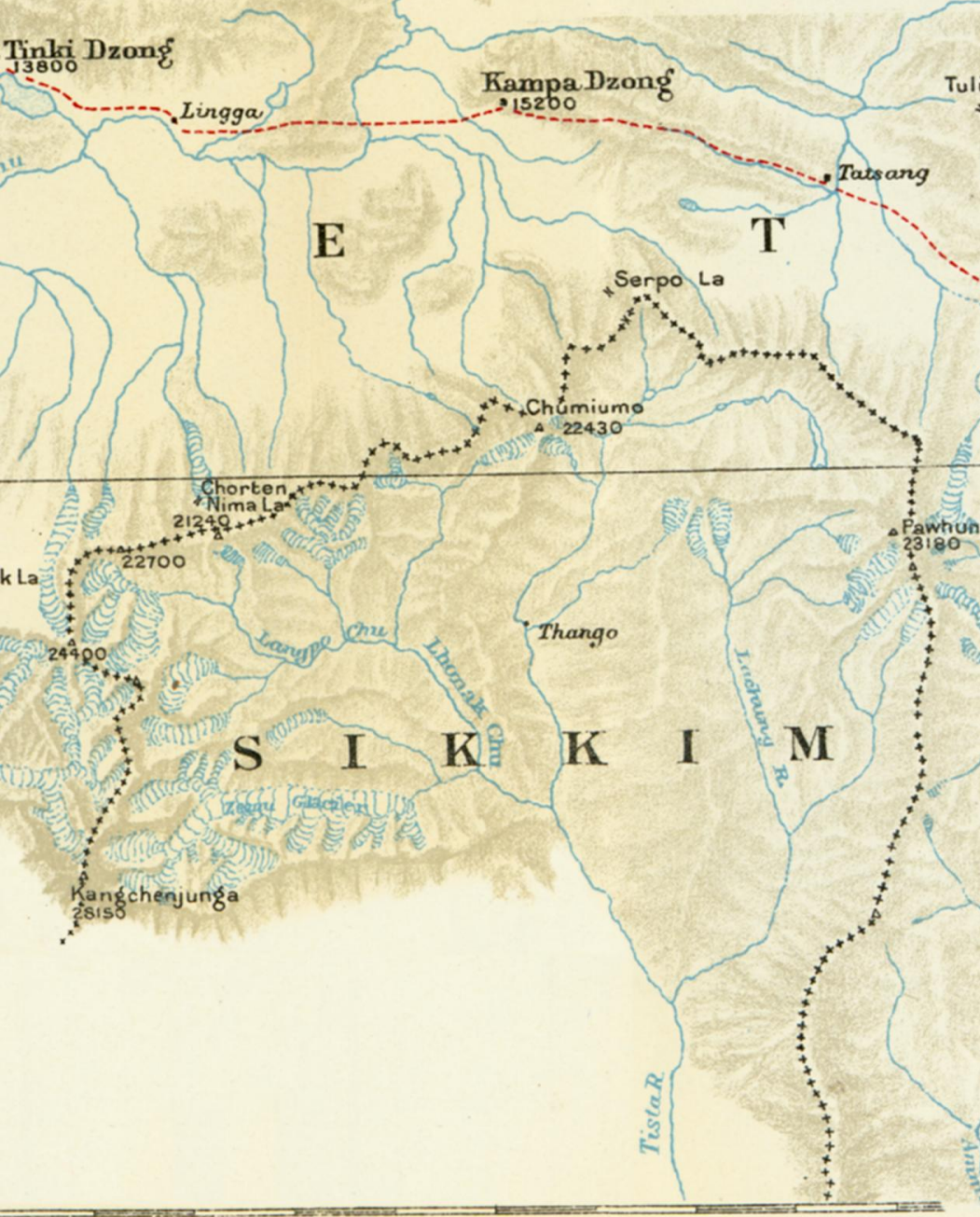

L

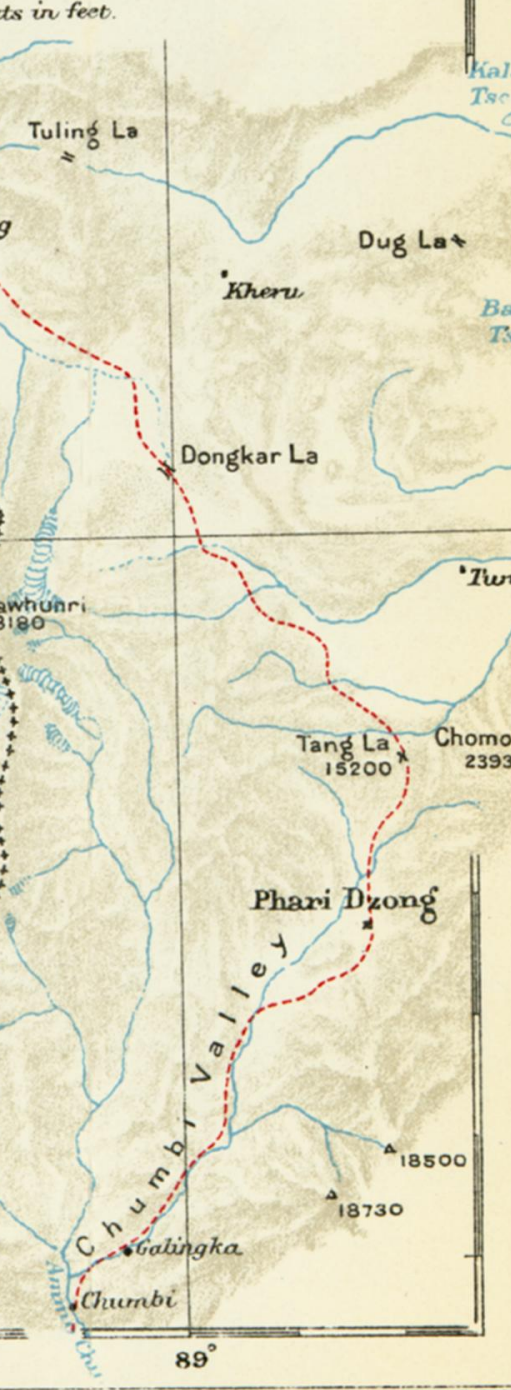

